\title{
THE EFFECTS OF ORGANIZATIONAL POLITICS AND STRATEGIC POSTURE ON INNOVATION PERFORMANCE
}

\author{
*Şevki ÖZGENER \\ **Adem ÖĞÜT \\ *Metin KAPLAN \\ *D. Mehmet BİCKES \\ *Nevşehir University \\ **Selçuk University
}

\begin{abstract}
Strategic posture is crucial to family-owned businesses for survival. In this study, we investigate the effects of organizational politics and strategic posture (as measured by the Miles-Snow strategic typology of prospectors, analyzers, defenders, and reactors) on innovation performance in familyowned businesses. The findings of the research indicated that prospectors were positively and significantly correlated with innovation performance. Similarly, innovation performance was found to be positively related to strategic posture of sector. The results showed that prospector was a significant predictor of innovation performance. According to the result of regression analysis, the interaction term of the perceptions of organizational politics and prospectors had a negative effect on innovation performance. However, the interaction of the perceptions of organizational politics and analyzers had a positive effect on innovation performance. Moreover, practical implications are discussed, and suggestions for the future research are made.
\end{abstract}

Keywords: Strategic Posture, Organizational Politics, Innovation Performance, and Family-Owned Business.

\section{INTRODUCTION}

Family-owned businesses have been the focus of numerous studies during the last few years due to their capacity to generate employment as well as their essential role in the wealth creation process (Garcia et al., 2007: 152). Researchers have suggested the use of multiple conditions to distinguish family from non-family business. Frequently used conditions include family ownership and control, family influence in decision making, operational aspects of a business, family members as employees and the intent to transfer the family firm to the next generation (Kotey, 2005: 395; Matlay, 2002: $361)$.

Innovation performance is commonly considered as a key component in family-owned businesses competing successfully in the market. In fact, the necessity for innovation of family-owned businesses has increased because of some factors such as shorter product cycles, increased segment fragmentation, increased competition and changing requirements of customer (Ozsomer et al., 1997: 401). However, there are some factors such as organizational structure, unqualified employees, lack of finance, poor organizational culture, organizational politics and strategic posture that affect family -owned businesses' innovation performance negatively. Particularly, the market environment in the 
manufacturing industry is likely to be more competitive in terms of product and product innovation than in other industries. Therefore, the goal of this study is to examine the effects of organizational politics and strategic posture on innovation performance for family-owned businesses in manufacturing industry.

\section{ORGANIZATIONAL POLITICS}

Organizational politics is an integral aspect of organizational life and relates to power, authority and influence. Over the years, scholars have tried to define organizational politics in various ways. Organizational politics is defined as "social influence attempts directed at those who can provide rewards that will help promote or protect the self-interest of the actor" (Haris et al., 2005: 29). Organizational politics can be viewed as intentional actions (either covert or overt) by individuals to promote and protect their self-interest, sometimes at the expense of and without regard for the wellbeing of others or their organizations (Byrne, 2005: 176).

Organizational politics is defined as "a social influence process in which behavior is strategically designed to maximize short-term or long-term self-interest, which is either consistent with or at the expense of others' interests'. Perceptions of organizational politics are fueled by conditions such as uncertainty about organizational decisions, ambiguity about expectations, procedures, or roles, and competition for scarce resources (Miller et al., 2008). Perceptions of politics usually reflect employees' views about the level of power and influence used by other organizational members to gain advantages and secure their interests in conflicting situations. The higher the perception of politics, the lower the sense of fairness and equal treatment, because people with more power are in a better position to satisfy their interests and needs at the expense of others who have less political resources and influence (Vigoda-Gadot et al., 2003: 766).

Previous empirical studies supported a direct and negative relationship between perceptions of organizational politics and job performance (Chen and Fang, 2008; Edwards, 2007; Zivnuska et al., 2004). Similarly, we assume that organizational politics perceptions have a negative influence on innovative performance. But a little research has been done about organizational politics and innovation performance.

\section{STRATEGIC POSTURE}

Strategic posture has received much attention and investigation in management literature over the last two decades (Di Benedetto and Song, 2003: 514). Strategic posture refers to the way an organization's decision makers respond to external demands. An active posture involves deliberate efforts to manage the impressions of important stakeholders. With a passive posture, no attempt is made to monitor stakeholder concerns, or to define an optimal stakeholder management strategy (Magness, 2006: 545). Undoubtedly, both active and passive postures have an effect on innovation performance of the businesses.

Strategic posture has an important impact on long-term performance. In connection with the strategic posture, in this study Miles and Snow's (1978) generic strategy typology will be taken up as references. Miles and Snow's classification of strategic behavior into four types is well known (Elwood Williams and TSE, 1995: 23). They contend that the prospector, defender and analyzer styles are capable of leading to competitive advantage within the industry. However, they caution that the reactor style is often a manifestation of a poorly aligned strategy and structure and therefore unlikely to lead to competitive advantage (Zahra and Pearce, 1990). Miles and Snow's typology of strategy is 
as follows (Elwood Williams and Tse, 1995: 23; O'Regan and Ghobadian, 2006: 606; Mavondo, 2000: 257; Parnell et al., 2000: 521):

Prospectors. Prospectors are characterized by a strong and consistent exploration of new markets, technological uses, product designs, and organizational operations. These tend to operate in volatile environments and are continually searching for market opportunities. In brief, prospector organizations are constantly seeking innovation in business. Most often, prospectors consider innovation as the organization's key competitive advantage

Analyzers. They watch competitors closely, then adopt the most promising new ideas using their efficient research and production skills. Analyzers stress both stability and flexibility and attempt to capitalize on the best of both of the preceding strategic types.

Defenders. These organizations tend to operate in a narrow and stable product-market domain. Top managers are highly expert in their organization's limited area of operation but do not tend to search outside the domain for new opportunities. Hence, defenders may be poorly placed to respond when customers' needs change. Primary attention is devoted to improving efficiency of existing operations and to avoid unnecessary risk.

Reactors. Reactors lack consistency in strategic choice and perform poorly. Management perceives change and uncertainty but is unable to cope with it. Change inevitably presents some difficulties. This strategy is not viable in the long term.

Many authors have highlighted the important role of strategic posture. However, a little research investigated the relationship between strategic posture and innovation performance. Ozsomer et al. (1997) examined organizational and environmental factors affecting innovativeness. They found that a prospector strategic posture strongly influenced innovation. Similarly, Tanewski et al. (2003) analyzed the relationship between strategic orientation and innovation performance in terms of family and non-family firms. Results indicated that strategic posture had a significant effect on innovation performance for both family and non-family businesses. Moreover, Jogaratnam and TSE (2006) examined whether or not entrepreneurial strategic orientation is associated with organizational structure within the context of the Asian hotel industry. Results suggested that entrepreneurial strategic posture was positively associated with performance. O'Regan and Ghobadian (2006) investigated the perceptions of generic strategies of small and medium sized engineering and electronics manufacturers. According to the findings of this study, prospectors tended to perceive their environment as "dynamic" whereas defenders perceived their environment as "stable".

\section{INNOVATION PERFORMANCE}

Innovation performance reflects the firm's ability to be a first user of new ideas, devices, systems, policies, programs, processes, product and services (Zehir and Ozsahin, 2008: 714). Innovation performance includes the number of innovations, speed of innovation, level of innovativeness (novelty or newness of the technological aspect), and being the "first" in the market (Prajogo and Sohal, 2003: 906). In the global competitive environment, having the higher level of the innovation performance is the basic desire of the business management. However, the organizational politics and the strategic posture of many firms have a distinctive effect on the innovation performance in the manufacturing industry. Although a little research has been done about this study (Oke, 2007), Zehir and Ozsahin (2008) analyzed the relationships of organizational factors and environmental factors affecting strategic decision-making speed and innovation performance. The results suggested that 
the strong relationships among participation, strategic decision speed and innovation performance were highlighted.

As we explained above, this study is needed because the researches relevant to the effects of organizational politics and strategic posture on innovation performance are limited. The research objective of this study is to investigate the effects of organizational politics and strategic posture (as measured by the Miles-Snow strategic typology of prospectors, analyzers, defenders, and reactors) on innovation performance in family-owned businesses. The following hypothesis will be tested in this respect:

H1: Perceptions of organizational politics will be negatively related to innovation performance.

H2: Prospectors will be positively related to innovation performance.

H3: Analyzers will be positively related to innovation performance.

H4: Defenders will be negatively related to innovation performance.

H5: Reactors will be negatively related to innovation performance.

H6: Perceptions of organizational politics will moderate the relationship between prospectors and innovation performance.

H7: Perceptions of organizational politics will moderate the relationship between analyzers and innovation performance.

H8: Perceptions of organizational politics and defenders have a negative impact on innovation performance.

H9: Perceptions of organizational politics and reactors have a negative impact on innovation performance.

\section{METHODOLOGY}

\section{Sample and Procedure}

The sampling consists of family-owned businesses in the manufacturing industry in the province of Konya, Turkey. The data for this survey are collected from managers of businesses in manufacturing industry listed in Konya Chamber of Industry. Interviewers were used to distribute questionnaires to the family-owned businesses.

In this study 200 family-owned businesses were randomly selected. A total of 68 questionnaires were returned, yielding a response rate of 34 percent. The demographic profiles of respondents are shown in Table 1. Of the 68 respondents, 92.6 percent were male and 7.4 percent were female. Almost 53 percent of the respondents were between 38 and 52 years old. $55.9 \%$ of those responding had more than 5 years of managerial experience. In terms of education levels, $20.6 \%$ of the respondents had graduated from primary school, $14.7 \%$ from secondary school and $29.4 \%$ from high school. 30.9 percent of the participants had a bachelor's degree and $4.4 \%$ had a master's degree or higher. 
Table 1: Demographic Characteristics of Sample

\begin{tabular}{|c|c|c|c|c|c|}
\hline Characteristics & f & $(\%)$ & Characteristics & $\mathbf{f}$ & $(\%)$ \\
\hline $\begin{array}{l}\text { Size of business (number of } \\
\text { employee) }\end{array}$ & & & $\begin{array}{l}\text { Managerial experience } \\
\text { (number of years) }\end{array}$ & & \\
\hline 1 to 25 & 26 & 38.2 & $0-5$ & 30 & 44.1 \\
\hline 26 to 50 & 28 & 41.2 & $6-10$ & 14 & 20.6 \\
\hline 51 to 75 & 4 & 5.9 & $11-15$ & 9 & 13.2 \\
\hline 75 or more & 10 & 14.7 & More than 15 & 15 & 22.1 \\
\hline Industry Category & & & Gender & & \\
\hline Metal industry, metal tools, ma- & 27 & 39.7 & Female & 5 & 7.4 \\
\hline chinery and equipment. & & & Male & 63 & 92.6 \\
\hline $\begin{array}{l}\text { Chemicals, oil products, rubber } \\
\text { and plastics }\end{array}$ & 15 & 22.1 & Age & & \\
\hline Food, beverages and tobacco & 6 & 8.8 & Less than 30 & 4 & 5.9 \\
\hline Automotive & 7 & 10.3 & $30-35$ & 20 & 29.4 \\
\hline Construction and Cement & 3 & 4.4 & $36-45$ & 28 & 41.2 \\
\hline $\begin{array}{l}\text { Others (textile, paper products, } \\
\text { electronics and computer etc.) }\end{array}$ & 10 & 14.7 & 45 or more & 16 & 23.5 \\
\hline Organizational title/rank & & & Education Level of Partici- & & \\
\hline $\begin{array}{l}\text { General manager (CEO, presi- } \\
\text { dent, general director) }\end{array}$ & 6 & 8.8 & $\begin{array}{l}\text { pants } \\
\text { Primary school }\end{array}$ & 14 & 20.6 \\
\hline Owners & 37 & 54.4 & Secondary school & 10 & 14.7 \\
\hline Division Manager & 15 & 22.1 & High school & 20 & 29.4 \\
\hline Other & 10 & 14.7 & Bachelor' degree & 21 & 30.9 \\
\hline & & & Master's degree or PhD & 3 & 4.4 \\
\hline Status of a person & & & & & \\
\hline Married & 53 & 77.9 & & & \\
\hline Single & 15 & 22.1 & & & \\
\hline
\end{tabular}

Respondents held a variety of positions in family-owned businesses. They included General Manager $(8.8 \%)$, Owners (54.4\%), Division Manager $(22.1 \%)$ and others $(14.7 \%)$. When industry category is taken into consideration, it is seen that the family-owned businesses that responded to the survey operate in metal and machinery industry (39.7 percent), chemicals and plastics industry (22.1 percent), food, beverages and tobacco industry (8,8 percent), construction and cement $(4,4$ percent) and other industries (14.7 percent). These firms operate in local markets (5.9\%), national markets $(48.5 \%)$ and international markets $(45,6 \%)$. Furthermore, $22.1 \%$ of the family-owned businesses responding to the survey don't allocate resources for R\&D. $17.9 \%$ of the businesses allocated more than five percent of resources for $R \& D$, while almost $60 \%$ of these businesses allocated only five percent of resources for R\&D.

\section{Measures}

Innovation performance was designated as the dependent variable in this study, while strategic posture and perceptions of organizational politics were considered as the independent variables. Existing scales were adopted to measure all three constructs. To measure perceptions of politics, we used the 15-items Perceptions of Organizational Politics Scale (POPS) developed by Kacmar and Carlson (1997). Participants responded on a 5-point Likert-type scale dictating to the extent which they agreed with each statement as it reflected their present work environment $(1=$ strongly disagree, $5=$ 
strongly agree). The internal reliability estimated for this sample was 0.76 . On the other hand, to measure strategic posture, we used strategic typology multi-item scale developed by Miles and Snow (1978) and adopted by Conant et al. (1990). The strategic typology contains 44 items which are designed to produce 11 scales of 4 items each.

In this study, each item of 11 scales represents the characteristics of prospector, analyzer defender and reactors in Miles and Snow's strategy typology. Firstly, typologies of 68 family-owned businesses were determined severally. For example, if most of respondents mark item which closely reflects the features of prospectors to determine the strategic posture of a business, the strategic posture of this business is accepted as a prospector. But the numbers of prospector and analyzer can be equal. In this case, if respondents mostly choose the item which best reflects the features of "defender"; the business is assumed as a prospector. If respondents mostly mark the item which best reflects the features of "reactors", the business is accepted as an analyzer. A similar procedure was used to determine the strategic posture for analyzers, defenders and reactors. Secondly, so as to establish the strategic posture of sector, 1, 2, 3 and 4 scores varying related to typology embraced by business for 11 scales of 4 items each were determined. If most of respondents mark item which reflects the features of prospectors, the business is evaluated as prospector (4 score), analyzer ( 3 score), defender ( 2 score) and reactor (1 score). On the contrary, If most of respondents mark item which reflects the features of reactors, the business is evaluated as prospector ( 1 score), analyzer ( 2 score), defender ( 3 score) and reactor (4 score). After scores were indicated on a scale from 1 to 4 , the strategic posture of sector was stated by estimating means of each scale. Finally, in order to be compatible with strategic consciousness, the final numerical value of the strategic posture of each typology was calculated by multiplying the means of the strategic posture of sector and the value of each typology (prospectors, analyzers, defenders and reactors).

In this study, innovation performance is measured with a three-item 5-point Likert scale (1=strongly disagree, 5=strongly agree) developed by Prajogo and Sohal (2006). The scale showed adequate reliability. The Cronbach's alpha coefficient was 0.92. In general, a value of 0.70 in the Cronbach's alpha is considered adequate in order to ensure reliability of the internal consistency of a scale (Nunnally, 1978).

\section{THE RESULTS}

Table 2 reports means, standard deviations, correlations among variables, and cronbach's alpha coefficients. As predicted, prospectors were positively and significantly correlated with innovation performance at the 0.01 level. The result supported H2. Also, there was a positive but not significant correlation between analyzers and innovation performance. Thus, H3 was not supported.

Defenders and reactors were negatively related to innovation performance but not significant. Thereby, H4 and H5 were not supported. On the other hand, innovation performance was a positively significant relation between strategic posture of sector $(r=0.289, p<0.05)$ and education $(\mathrm{r}=0.258, \mathrm{p}<0.01)$. However, perceptions of organizational politics were found to be positively related to innovation performance, although the relationship was not statistically significant. Thus, H1 was not supported by the results. Furthermore, the correlation between perceptions of organizational politics and strategic posture of sector was negative but not statistically significant. 
Table 2: Descriptive Statistics and Inter-correlations among Study Variables

\begin{tabular}{|c|c|c|c|c|c|c|c|c|c|c|c|}
\hline $\bar{z}$ & & & & & & & & & & & $\begin{array}{l}\widehat{\delta} \\
\hat{e}\end{array}$ \\
\hline$\Theta$ & & & & & & & & & & - & 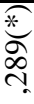 \\
\hline a & & & & & & & & & $\begin{array}{l}\stackrel{6}{e} \\
\stackrel{e}{e}\end{array}$ & $\begin{array}{l}\overrightarrow{\widehat{c}} \\
\underline{\varphi}\end{array}$ & $\begin{array}{l}\infty \\
0 \\
0\end{array}$ \\
\hline$\infty$ & & & & & & & & & $\begin{array}{l}\infty \\
\stackrel{0}{0} \\
0 \\
0\end{array}$ & $\begin{array}{l}\overrightarrow{\hat{N}} \\
\tilde{\sigma}\end{array}$ & $\begin{array}{l}\overrightarrow{\hat{\sigma}} \\
\dot{0}\end{array}$ \\
\hline$\pi$ & & & & & & & & 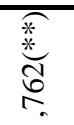 & $\begin{array}{l}\infty \\
0 \\
0 \\
0 \\
0 \\
1\end{array}$ & 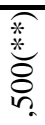 & $\begin{array}{l}\overline{8} \\
8 \\
0\end{array}$ \\
\hline 6 & & & & & & & 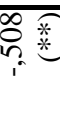 & 霂 & $\begin{array}{l}\overline{\widetilde{O}} \\
\bar{i}\end{array}$ & 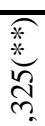 & $\begin{array}{l}\bar{I} \\
\overline{0}\end{array}$ \\
\hline$\pi$ & & & & & & $\stackrel{\infty}{?}$ & 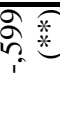 & 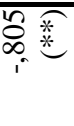 & $\begin{array}{l}\infty \\
0 \\
0 \\
0 \\
1\end{array}$ & 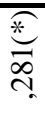 & 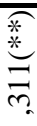 \\
\hline$\nabla$ & & & & & 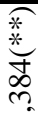 & 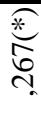 & $\begin{array}{l}8 \\
\end{array}$ & $\overline{9}$ & $\begin{array}{l}\widehat{T} \\
0 \\
0\end{array}$ & $\begin{array}{l}\text { Tे } \\
0 \\
0 \\
\end{array}$ & 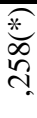 \\
\hline ल & & & $\overline{-}$ & $\begin{array}{l}\overrightarrow{0} \\
0 \\
0\end{array}$ & $\begin{array}{l}\text { ర్ } \\
\text { రे } \\
0\end{array}$ & 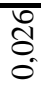 & $\begin{array}{l}\frac{m}{2} \\
\vdots \\
0\end{array}$ & $\begin{array}{l}\text { o } \\
0 \\
0 \\
0 \\
0\end{array}$ & 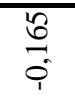 & $\begin{array}{l} \\
8 \\
0\end{array}$ & $\begin{array}{l}\infty \\
\stackrel{0}{0} \\
0 \\
\end{array}$ \\
\hline $\bar{N}$ & & & $\frac{\pi}{0}$ & 䍃 & $\begin{array}{l}\text { डे } \\
\text { ¿े }\end{array}$ & के & $\begin{array}{l}\text { 胥 } \\
\text { הู }\end{array}$ & $\begin{array}{l}\text { तु } \\
\frac{0}{1}\end{array}$ & $\stackrel{\substack{*\\
}}{a}$ & $\begin{array}{l}\text { के } \\
\text { के }\end{array}$ & $\begin{array}{l}\stackrel{m}{ \pm} \\
\dot{p}\end{array}$ \\
\hline$\overline{7}$ & & $\begin{array}{l}\bar{\sigma} \\
\stackrel{0}{0}\end{array}$ & $\frac{9}{1}$ & . & $\begin{array}{l}\text { 蛹 } \\
\text { तn }\end{array}$ & 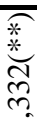 & 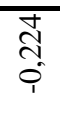 & 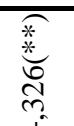 & $\tilde{O}_{0}$ & $\mathbb{O}_{0}^{0}$ & $\begin{array}{l}\infty \\
\text { त̂ } \\
0 \\
0\end{array}$ \\
\hline की & $\bar{\sigma}$ & $\stackrel{n}{=}$ & I & $\begin{array}{l}8 \\
\text { i }\end{array}$ & ल) & $\begin{array}{l}\text { N1 } \\
\text { in }\end{array}$ & $\begin{array}{l}\bar{b} \\
i\end{array}$ & $\underset{\dot{f}}{\stackrel{T}{m}}$ & 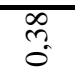 & İ & $\begin{array}{l}0 \\
0\end{array}$ \\
\hline$\sum_{\bar{\Sigma}}^{\bar{\pi}}$ & $\hat{S}$ & $\begin{array}{l}\infty \\
i \\
i\end{array}$ & $\stackrel{m}{i}$ & $\begin{array}{l}2 \\
\text { in }\end{array}$ & $\begin{array}{l}\text { di } \\
\text { n. }\end{array}$ & त̂ & त̂ & $\begin{array}{l}\infty \\
\text { in }\end{array}$ & $\begin{array}{l}\text { Tु } \\
\text { i }\end{array}$ & $\underset{i}{\stackrel{N}{i}}$ & $\begin{array}{l}\overline{9} \\
\text { m. }\end{array}$ \\
\hline & 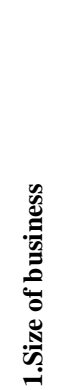 & 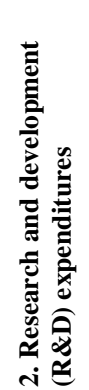 & 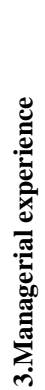 & 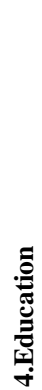 & 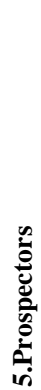 & 离 & 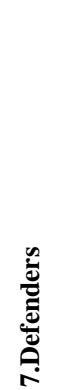 & 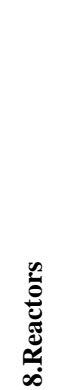 & 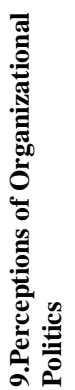 & 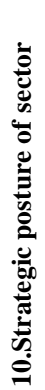 & 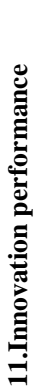 \\
\hline
\end{tabular}

* Correlation is significant at the 0.05 level (2-tailed).

** Correlation is significant at the 0.01 level (2-tailed).

Note: Correlations are relatively high among prospectors, analyzers, defenders and reactors since the means of the strategic posture of sector were used to calculate the numerical value of the strategic posture of each typology. 
Hierarchical regression was used to test the hypotheses. Initially, the block of control variables were introduced into the model, followed by the appropriate independent and moderating variables. VIF values less than ten are often taken to indicate minimal collinearity. The VIF did not exceed 5.1 in all cases and it was therefore concluded that multi-collinearity was not a serious problem for the regression analyses that follow.

Table 3 presents the results of the hierarchical regression analysis. As it can be observed, the regression coefficients representing the main effect of prospectors on innovation performance are positive and significant. As expected, the results showed that prospector was a significant predictor of innovation performance $(\beta=0.200 ; \mathrm{p}<0.01)$. But Research and Development (R\&D) expenditures had a negative and significant effect on innovation performance $(\beta=-0.259 ; \mathrm{p}<0.01)$.

The results show that Model 3 is significant $\left(\mathrm{R}^{2}=0.468 ; \mathrm{F}_{(13-54)}=3.648 ; \mathrm{p}<0.05\right)$. The interaction terms explained additional 11.3 percent of the variance in innovation performance. For innovation performance, Model 3 shows that the regression coefficient associated with the interaction term of the perceptions of organizational politics and prospectors is negative and statistically significant $(\beta=$ -0.253; $\mathrm{p}<0.05$ ). This result did not support H6. That is, the interaction term had a negative and statistically significant effect on innovation performance. However, the coefficient for the interaction between the perceptions of organizational politics and analyzers is positive and significant $(\beta=$ $0.360 ; \mathrm{p}<0.05)$ for innovation performance. Thus, H7 was not supported by the results.

Moreover, the interaction between Perceptions of Organizational Politics (POPs) and defenders is negative and not significant for innovation performance $(b=-0.028 ; p>0.05)$. Similarly, the coefficient for the interaction between POPs and reactors is negative and not significant $(b=-.77, p<.01)$. As it can be observed, $\mathrm{H} 8$ and $\mathrm{H} 9$ were not supported by the results reported in Table 3. 
Table 3: The Results of Hierarchical Regression Analyses: The Effects of Organizational Politics and Strategic Posture on Innovation Performance

\begin{tabular}{|c|c|c|c|c|c|}
\hline Independent variables entered & b & S.E. & t-value & $\mathbf{R}^{2}$ & $\mathbf{R}^{2}$ Change \\
\hline Model 1: Control variables $F(4-63)=3,161$ & & & & 0.167 & \\
\hline Size of business & 0,148 & 0,11 & 1,34 & & \\
\hline Managerial experience & $-0,004$ & 0,089 & $-0,049$ & & \\
\hline Research and development (R\&D) expenditures &,$- 234 *$ & 0,1 & $-2,331 *$ & & \\
\hline Education &, $216^{*}$ & 0,09 & $2,400 *$ & & \\
\hline Model 2: Main effects $F(9-58)=3,540$ & & & & 0.355 & 0.187 \\
\hline Size of business & 0,188 & 0,107 & 1,745 & & \\
\hline Managerial experience & 0,001 & 0,083 & 0,012 & & \\
\hline Research and development (R\&D) expenditures &,$- 259 * *$ & 0,098 & $-2,648 * *$ & & \\
\hline Education & 0,169 & 0,09 & 1,88 & & \\
\hline Perceptions of Organizational Politics & $-0,097$ & 0,241 & $-0,405$ & & \\
\hline Prospectors & ,200** & 0,051 & $3,893 * *$ & & \\
\hline Analyzers & $-0,118$ & 0,072 & $-1,625$ & & \\
\hline Defenders & 0,039 & 0,061 & 0,643 & & \\
\hline Reactors & 0,095 & 0,062 & 1,542 & & \\
\hline Model 3: Interaction effects $F(13-54)=3,648$ & & & & 0.468 & 0.113 \\
\hline Size of business &, $216^{*}$ & 0,102 & $2,119 *$ & & \\
\hline Managerial experience & 0,011 & 0,082 & 0,134 & & \\
\hline Research and development (R\&D) expenditures &,$- 309 * *$ & 0,094 & $-3,293 * *$ & & \\
\hline Education & 0,135 & 0,087 & 1,561 & & \\
\hline Perceptions of Organizational Politics & $-0,257$ & 1,81 & $-0,142$ & & \\
\hline Prospectors &, $814 *$ & 0,266 & $3,065^{*}$ & & \\
\hline Analyzers &,$- 984 *$ & 0,409 & $-2,405^{*}$ & & \\
\hline Defenders & 0,08 & 0,351 & 0,228 & & \\
\hline Reactors & 0,45 & 0,321 & 1,403 & & \\
\hline Perceptions of Organizational Politics* Prospectors &,$- 253 *$ & 0,109 & $-2,319 *$ & & \\
\hline Perceptions of Organizational Politics* Analyzers &, $360 *$ & 0,167 & $2,154^{*}$ & & \\
\hline Perceptions of Organizational Politics* Defenders & $-0,028$ & 0,144 & $-0,197$ & & \\
\hline Perceptions of Organizational Politics* Reactors & $-0,14$ & 0,129 & $-1,082$ & & \\
\hline \multicolumn{6}{|c|}{ Notes: $\beta$ indicates unstandardized regression coefficient. $* \mathrm{p}<0.05 ; * * \mathrm{p}<0.01$} \\
\hline Dependent variables: Innovation performance & & & & & \\
\hline
\end{tabular}




\section{CONCLUSION}

The topics of perceptions of organizational politics and strategic posture have received increasing attention from the field of organizational behaviour and strategic management. This study has investigated the effects of organizational politics and strategic posture on innovation performance in family-owned businesses in the province of Konya-Turkey. As predicted, prospectors were found to be positively and significantly correlated with innovation performance. The result is consistent with previous studies that have shown that there is strong positive correlation between strategic posture and innovation performance. Particularly, Ozsomer et al. (1997) showed that a prospector strongly influenced innovation. Similarly, Tanewski et al. (2003) indicated that strategic posture had a significant effect on innovation performance for both family and non-family businesses. Moreover, Jogaratnam and Tse (2006) suggested that entrepreneurial strategic posture was positively associated with performance.

Similarly, innovation performance was found to be positively significant relation between strategic posture of sector and education. On the other hand, defenders and reactors were negatively related to innovation performance but not significant. However, perceptions of organizational politics were found to be positively related to innovation performance, although the relationship was not statistically significant. Furthermore, the correlation between perceptions of organizational politics and strategic posture of sector was negative but not statistically significant.

The results of regression analyses showed that prospector was a significant predictor of innovation performance. The interaction term of the perceptions of organizational politics and prospectors had a negative and statistically significant effect on innovation performance. However, the interaction of the perceptions of organizational politics and analyzers is positive and significant for innovation performance. On the other hand, both the interaction of POPs and defenders, and the interaction of POPs and reactors were negatively and not significant for innovation performance. These results were supported by previous theoretical arguments and empirical evidence favouring the negative effect of perceptions of organizational politics on performance (Chen and Fang, 2008; Edwards, 2007; Zivnuska et al., 2004).

These results should be viewed in light of some possible limitations of this study. Firstly, we developed new procedure to calculate the numerical values of the typologies of strategic posture. The reliability of the procedure utilized in this study hasn't been proven yet in many different settings/ countries. The second limitation is that this study has been conducted in family-owned businesses in a single-city setting (Konya). As a result, the generalizability of the findings might be limited. Consequently, additional researches across different industries and countries will be required in order to generalize the findings.

This research aimed to investigate the effects of organizational politics and strategic posture on innovation performance in family-owned businesses. For the upcoming research, it is available to investigate the strategic posture among different industries. Moreover, it would also be interesting to establish the relationships between strategic intent and strategic posture for different industries or organizations. 


\section{REFERENCES}

Byrne, Z. S. (2005), Fairness reduces the negative effects of organizational politics on turnover intentions, citizenship behavior and job performance, Journal of Business and Psychology, 20 (2): 175 -200 .

Chen, Y., and Fang, W. (2008), The moderating effect of impression management on the organizational politics-performance relationship, Journal of Business Ethics, 79: 263-277.

Conant, J. S., Mokwa, M. P. and Varadarajan, P. R. (1990), Strategic types, distinctive marketing competencies and organizational performance: A Multiple-measures-based study, Strategic Management Journal, 11: 365-383.

Di Benedetto, C. A., and Song, M. (2003), The relationship between strategic type and firm capabilities in Chinese firms, International Marketing Review, 20 (5): 514-533.

Edwards, T. (2007), Organizational politics and the "process of knowing": understanding crisis events during project-based innovation projects, European Journal of Innovation Management, 10 (3): 391-406.

Elwood Williams, C., and Tse, E. C. Y. (1995), The relationship between strategy and entrepreneurship: The US Restaurant Sector, International Journal of Contemporary Hospitality Management, 7 (1): $22-26$.

Garcia, D., Lema, P. and Durendez, A. ( 2007), Managerial behaviour of small and medium-sized family businesses: an empirical study, International Journal of Entrepreneurial Behaviour \& Research, 13 (3): 151-172

Harris, K. J., James, M., and Boonthanom, R. (2005), Perceptions of organizational politics and cooperation as moderators of the relationship between job strains and intent to turnover, Journal of Managerial Issues, XVII (1): 26-42.

Jogaratnam, G. , and Tse, E. C. (2006), Entrepreneurial orientation and the structuring of organizations: Performance evidence from the Asian hotel industry, International Journal of Contemporary Hospitality Management, 18 (6): 454-468.

Kacmar, K. M., and Carlson, S. D. (1997), Further validation of the perceptions of politics scale (pops): a multiple sample investigation, Journal of Management, 23(5): 627-658.

Kotey, B. (2005), Are performance differences between family and non-family SMEs uniform across all firm sizes?, International Journal of Entrepreneurial Behaviour \& Research, 11 (6): 394421

Magness, V. (2006), Strategic posture, financial performance and environmental disclosure: An empirical test of legitimacy theory, Accounting, Auditing \& Accountability Journal, 19 (4): 540-563.

Matlay, H. (2002), Training and HRD strategies in family and non-family owned small businesses: A comparative approach, Education+Training, 44 (8/9): 357-369.

Mavondo, F. T. (2000), Marketing as a form of adaptation: Empirical evidence from a developing economy, Marketing Intelligence \&Planning, 18(5): 256-272. 
Miles, R. and Snow, C. (1978), Organizational strategy, structure, and process, New York, McGraw -Hill.

Miller, B. K., Rutherford, M. A., and Kolodinsky, R. W. (2008), Perceptions of organizational politics: A meta-analysis, of outcomes, Journal of Business Psychology, 22: 209-222.

Nunnaly, J. C. (1978), Psychometric theory, 2nd edn. New York, McGraw-Hill.

O'Regan, N., and Ghobadian, A. (2006), Perceptions of generic strategies of small and medium sized engineering and electronics manufacturers in the UK: The applicability of the Miles and Snow Typology, Journal of Manufacturing Technology Management, 17 (5): 603-620.

Oke, A. (2007), Innovation types and innovation management practices in service companies, International Journal of Operations \& Production Management, 27 (6): 564-587.

Ozsomer, A.., Calantone, R. J., and Di Benedetto, A. (1997), What makes firms more innovative? A look at organizational and environmental factors, Journal of Business \& Industrial Marketing, 12 (6): 400-416.

Parnell, J. A., Lester, D. L., and Menefee, M. L. (2000), Strategy as a response to organizational uncertainty: An alternative perspective on the strategy-performance relationship, Management Decision, 38(8): 520-530.

Prajogo, D. I., and Sohal, A. S. (2003), The relationship between TQM practices, quality performance, and innovation performance: An empirical examination, International Journal of Quality \& Reliability Management, 20 (8): 901-918.

Prajogo, D.I. and Sohal, A.S. (2006), The integration of TQM and technology/R\&D management in determining quality and innovation performance, International Journal of Management Science, 34: 296-312.

Tanewski, G. A., Prajogo, D., and Sohal, A. (2003), Strategic orientation and innovation performance between family and non-family firms, Proceedings of the 48th World Conference of the International Council of Small Business, 15-18 June, Belfast: 1-22.

Vigoda-Gadot, E., Vinarski-Peretz, H., and Ben-Zion, E. (2003), Politics and image in the organizational landscape: An empirical examination among public sector employees, Journal of Managerial Psychology, 18 (8): 764-787.

Zahra, S. A., and Pearce, J. A. (1990), Research evidence on the Miles-Snow Typology, Journal of Management, 16 (4): 751-768.

Zehir, C., and Ozsahin, M. (2008), A field research on the relationship between strategic decisionmaking speed and innovation performance in the case of Turkish large-scale firms, Management Decision, 46 (5): 709-724.

Zivnuska, S., Kacmar, K. M., Witt, L.A., Carlson, D.S., and Bratton, V. K. (2004), Interactive effects of impression management and organizational politics on job performance, Journal of Organizational Behavior, 25: 627-640. 